\title{
Optimization problems for body technique instruction age from analysis of average age of skill acquisition using discrimination and difficulty parameters
}

\author{
Atsuko Shimoda ${ }^{1}$, Seiji Ohsawa ${ }^{1}$ and Tomoya Okubo
}

\begin{abstract}
Because of rapid social changes in preliterate societies, 'body techniques' (in this study, clothes-making skills) that are passed down from generation to generation are in danger of disappearing. There are currently efforts at local vocational schools to develop practical training methods and curriculums to preserve traditional skills. To help these efforts, research is being done both on the tools and materials for clothes-making, and on a rational and effective system of instruction. In this study, 106 subjects were surveyed to determine whether they had acquired 34 carefully selected traditional clothes-making skills. For each skill, the average age of skill acquisition $\bar{x}$ and Item Response Theory-derived difficulty parameters $(\beta)$ and discrimination parameters $(\alpha)$, were used to investigate the optimal timing for traditional skills instruction.

We surveyed 106 Karen women in Chiang Mai Province, Thailand with clothes-making experience. For each skill, we sought the above-mentioned parameters $(\alpha)$ and $(\beta)$, the average age of skill acquisition $\bar{x}$, and the standard deviation $(\sigma)$. Analysis of the indifference curves obtained from plotting $(\alpha)$, $(\beta)$, and $(\sigma)$ vs. $\bar{x}$ in a two-dimensional figure, clearly pointed to a solution for this optimization problem. We found out useful information about the optimal age for teaching each skill. Furthermore, we think that we can use this same method for similar optimization problems relating to the transmission of traditional skills.
\end{abstract}

Key words : preliterate society, developmental task, making of clothes, body techniques, item response theory

\section{Objective and Significance of Research}

Since Mauss (1950) first described the "Techniques of the Body", many social anthropologists have continued investigating the topic (Hewes, 1955 ; Iwata, 1971 ; Kawada, 1988 ; Kawada, 1991 ; Tanabe, 1997). However, quantitative research, such as the study of factor structures of exercise capacity (Matsuura, 1968) and work competency (Mori, 1985), has been rare. To present, there has been no research on our topic, the factor structure and learning order of fabric manufacturing.
In a preliterate society, knowledge and skills are transmitted orally, by gestures, encoded communication, and medium of tools for clothes-making. In this research, the topic of investigation was how body techniques for clothes-making are transmitted, and to determine order within the teaching/ learning system in the preliterate Karen society of the mountainous regions of Southeast Asia. (note)

At present the Karen society is rapidly confronting the tide of modernization, as are other preliterate societies. In the past, Karen women would traditionally learn clothes-making over a period of years, watching their mothers and 
grandmothers work. The growing and harvesting of cotton, making thread, cloth, and clothes, made up a series of body techniques whose mastery was a basic hallmark of adulthood and cultivation. In Karen society, clothes making skills were extremely important body techniques, and the most important developmental task in the growth process of adolescent women (Shimoda and Ohsawa, 2006).

However, with the spread of factory-made clothing, opportunities for Karen women to make clothing for themselves or their family are dwindling, and the traditional culture is disappearing. Perhaps realizing the gravity of this situation, there have been recent efforts in school education (initiated by the Thai government) to preserve Karen clothes-making skills. Locally, the present challenge is how to incorporate the traditional learning process into the school-based curriculum, and how and who should teach these skills in the limited class time.

We believe that, beginning with the Karen society, Item Response Theory（IRT） can be used to great effect in considering how to teach traditional skills in preliterate societies as part of a modern educational system.

In existing research, "difficulty" has been expressed in terms of pass-rates and average values, but as these values were dependent on the measurement group, they are not appropriate indices for expressing item-specific difficulty. Because Item Response Theory allows expression of difficulty independent of measurement group, and values can be consistently interpreted using a same scale even in different surveys, we use this method in our current research.

To present, the authors have elucidated two main points. (1) The order in which Karen women (138 women, ages 12-74) acquired 12 main weaving skills depended on the relative difficulty of these skills (Shimoda and Ohsawa, 2006). (2) When Item Response Theory (IRT) (Ohtomo, 1996) (Toyoda, 2002) was used to estimate the difficulty (item characteristic) of the 34 main clothes-making skills, the resulting logarithmic curve for a specific body technique/skill acquisition process was highly similar to the learning curve.

It can be inferred from the clearly progressive nature and mathematical order to the acquisition of clothes-making skills by the Karen that there is latently systematic learning system. In our own research, we investigate the relationship between the variable 'average age of skill acquisition' to the discrimination parameters and difficulty parameters estimated using IRT (Shimoda and Ohsawa, 2008). With the introduction of the variable 'age', the optimal age to teach/learn the 34 main clothes-making skills can be suggested. Furthermore, by looking at the skills grouped by type of skill, an even more detailed teaching-age optimization problem can be approached.

\section{Research Methods}

\section{Data Collection}

The survey was conducted in 2005. The subjects were 106, 12-18 year old Karen women living in the Samoeng district of Chiangmai province, Thailand. The Karen ethnic group are divided between the Sgaw Karen and Pwo Karen, but this research focused on the Sgaw Karen.

Over a ten years (beginning in 1996) and dozens of visits to the Thai Karen have been used to conduct participatory fieldwork and oral surveys to gather information on the clothes-making body techniques inherited from their ancestors (as the Karen understand it). We have also collected more than 100 examples of Karen traditional clothing. The result of these efforts is a clear definition of the 6-step process of transforming raw materials into clothing (cotton cultivation $\rightarrow$ thread-making $\rightarrow$ thread dyeing $\rightarrow$ weaving $\rightarrow$ sewing $\rightarrow$ cloth edge finishing) and the 148 body techniques/skills used in this process. Following this, we conducted a survey of 106, 12-18 year old Karen women who 
were in the process of learning these 148 clothes $^{-}$ making skills, asking whether they had acquired these skills as well as their age and other attributes. For data analysis, we assigned a value of 1 to 'skill acquired' and 0 to 'skill not acquired' ("Clothes-Making Skill Acquisition" data).

\section{Data Set}

In our research (Shimoda and Ohsawa, 2008) we conducted IRT ex ante analysis on the principle 43 clothes-making skills in the "ClothesMaking Skill Acquisition” data. We then estimated the item characteristic parameters for the 34 skills that were compatible with IRT analysis (Table 1). To estimate the parameters 'discrimination' and 'difficulty' using an IRT analysis model, we used a two parameter logistic model. Calculations were done with M-plus (version 2.14). We made data sets that combined the estimated values for 'discrimination' $(\alpha j)$ and 'difficulty' $(\beta j)$ for each of the 34 skills, with the proportion of women who had acquired the skill (pass-rate $(p j)$ ), average age $(\bar{x} j)$, and the standard deviation $(\sigma j)$ at time of skill acquisition. Here ' $j$ ' indicates the item as follows.

Where are the denotes of these terms.

\section{1) Item Discrimination $(\alpha j)$}

[Parameter estimated using IRT. Indicates to what extent the ability (ability to make clothes) trying to be measured in item $(j)$ is explained by the factor (the 34 skills)]

\section{2 ) Item Difficulty $(\beta j)$}

[Parameter estimated using IRT. Indicates the difficulty of the 34 skills]

\section{3) Pass-Rate $(p j)$}

[Indicates the proportion of people who acquired the 34 skills]

4 ) Average Age of Skill Acquisition $(\bar{x} j)$

[Indicates the mean value of the age of respondents who had acquired the 34 skills]

5 ) Standard Deviation $(\sigma j)$

[Indicates the standard deviation of the age of respondents who had acquired the 34 skills]

\section{Results and Discussion}

\section{Observations about the correla- tional scatter grams of average age of skill acquisition and stand- ard deviation, discrimination, diffi- culty}

After computing the average age and standard deviation of subjects who had acquired the 34 skills, we analyzed the relationship between the average age of skill acquisition and variation in skill acquisition. The lowest average age of skill acquisition was 15 years and the highest 17.5 years. In Figure 1, “average age of skill acquisition $(\bar{x} j)$ " is on the horizontal axis and "standard deviation $(\sigma j)$ " is on the vertical axis. As $\bar{x} j$ increases, $\sigma j$ decreases. In other words, as age increases, the individuals have built a foundation of skills and abilities, and variation in the pass ${ }^{-}$ rate of new skills decreases. For example, the variation between individuals' skills acquisition at age 17 was $1 / 3$ less than that at age 15 . In other words, as age increases, underachievement becomes rarer. Furthermore, between age 16.5 and 17 there is a marked change visible. It seems to indicate that in addition to acquiring even more accomplished skills, this is an important transitional period.

Next we analyzed to what extent we could measure clothes-making ability from the " 34 clothes-making skills" data, and also considered the relationship of this to increasing age. In Figure 2 , "average age of skill acquisition $(\bar{x} j)$ " is on the horizontal axis and "discrimination $(\alpha j)$ " is on the vertical axis. Until age 16, both progress in an almost straight line, but after age $16.5 \alpha j$ suddenly exhibits wide variation. Perhaps clothes-making skills learned after this time are difficult to acquire if a certain level of clothes-making skills have not already been mastered. This Figure suggest that during this crucial period, systematic and wellordered instruction and teaching materials, developed through scientific research, is needed to 
Table 1 Principal Clothes Making Techniques of the Karen

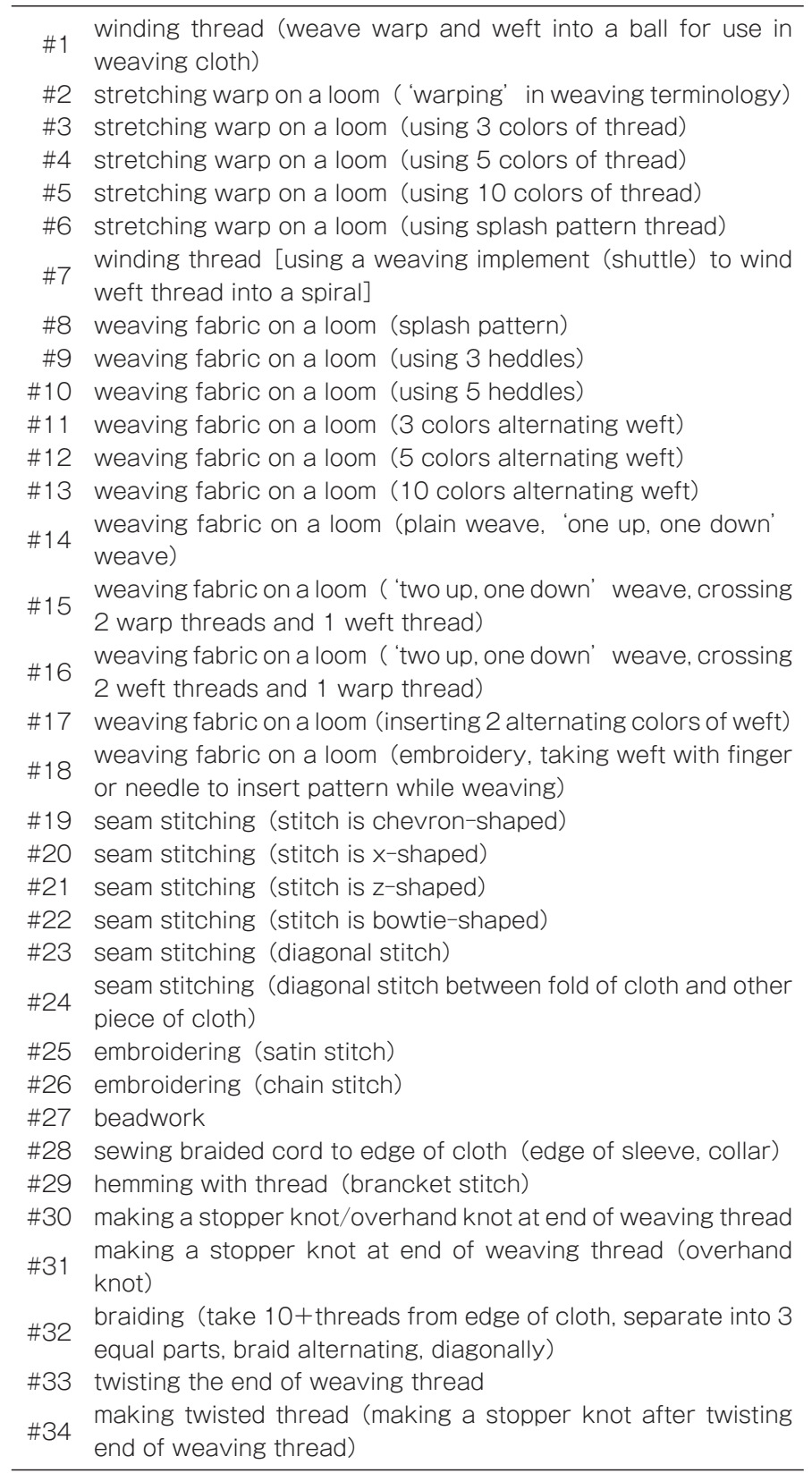

\#2-6 : Stretching warp in a coil around the loom with the one hand while holding 2 threads in the other hand.

prevent underachievement. Perfunctory skill acquisition at this turning point of 16.5 years becomes very difficult. Skills with a low $\alpha j$ are not essential clothes-making skills, and as age decreases, such skills are easy to acquire.
We also investigated the relationship between increasing average age of skill acquisition and the difficulty of the 34 skills using a correlation figure. In Figure 3, "average age of skill acquisition $(\bar{x} j)$ " is on the horizontal axis and "difficulty $(\beta j)$ " is on 


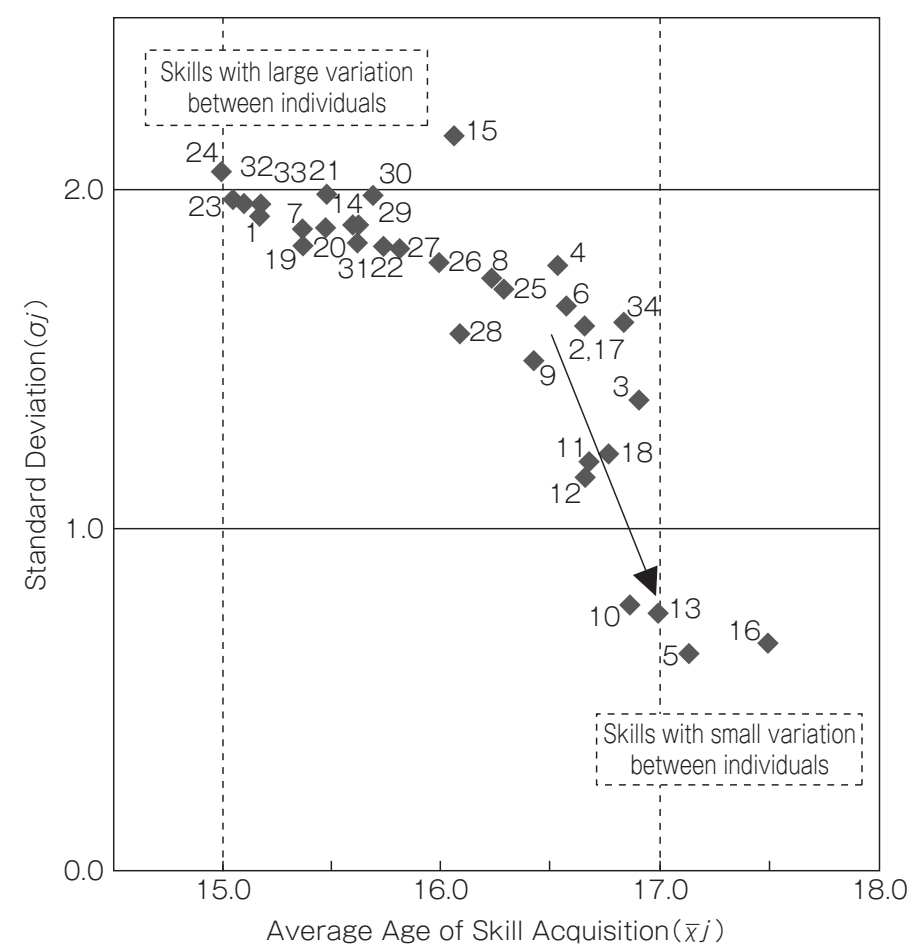

Figure 1 Average Age of Clothes Making Skill Acquisition (34 skills) and Standard Deviation for Karen Teenage Women (106 women)

the vertical axis. The resulting logarithmic curve is an upper left-facing convex arc beginning at the origin. It is clear that as age increases, high difficulty tasks are acquired. The closest skill to the origin is the easiest skill, "\#23 seam stitching (diagonal stitch)", and is mastered at age 15.0. However, at the same 15.0 years of age, four more skills appear above \#23. Although acquired at the same age 15 , we can see that there is a large difference in skill difficulty. If we order these scientifically, \#23 would be placed on the bottom, followed by \#1 $\rightarrow \# 32 \rightarrow \# 24 \rightarrow \# 33$. It is possible that this would be the most effective order in which to teach these skills.

\section{Existence of an Indifference curve}

In Figure 3, we can confirm the sequential nature of difficulty as it follows an increase in average age of skill acquisition. However, because completely different types of skills are grouped together in the 34 skills, it would be unsystematic to teach these skills based only in order of difficulty. It is therefore necessary to break down these curves by type of skill.

We divided the skills into the four groups below, and analyzed the optimal order of skill acquisition by kind of skill and age. In Figure 4, there are 4 Figures, one for each type of skill, with the "average age of skill acquisition $(\bar{x} j)$ " on the horizontal axis and "difficulty $(\beta j)$ " on the vertical axis.

The 4 Types of Skills :

1) Stretching warp on a loom ('warping' in weaving terminology)

2 ) Weaving fabric on a loom

3 ) Sewing cloth together, embroidering with needle and thread

4 ) Finishing the edge threads of woven cloth 


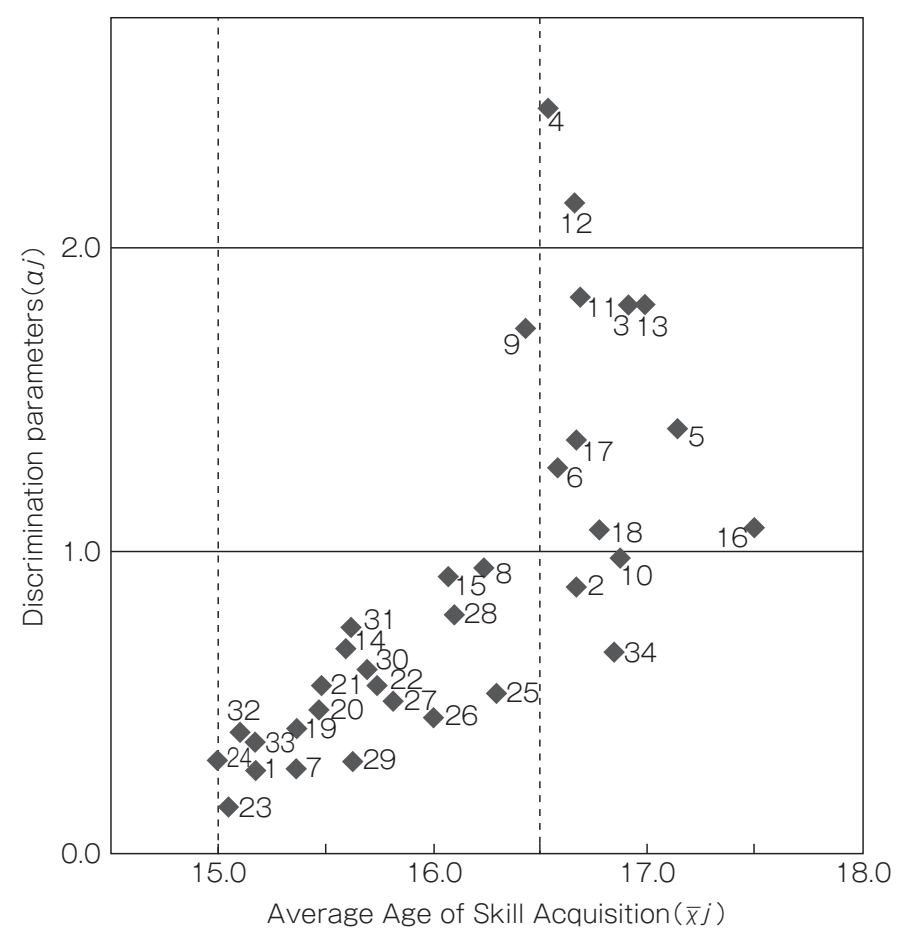

Figure 2 Average Age of Clothes Making Skill Acquisition (34 skills) and Discrimination parameters for Karen Teenage Women (106 women)

(braiding, tying, twisting, hemming)

$1)$ The figure for "Stretching warp on a loom" (Figure 4-1) is composed of 6 skills (Table 1, \#1$\# 6$ ). In this figure the skill with lowest average age of skill acquisition and difficulty is "\#1. winding thread (weave warp and weft into a ball for use in weaving cloth)" at 15.2 years. It is logical to call this skill \#1, as a ball of thread is needed before the warp can be stretched on the loom. From the figure we can see that more than a year after learning skill \#1, women are learning skill \#4, "stretching warp on a loom". In this type of skill, women spend a relatively large amount of time on the fundamental skill \#1.

Sorting the 6 skills in this figure by age gives the following results. At age 16, 4 skills are acquired, in order of increasing difficulty $\# 2 \rightarrow \# 3 \rightarrow \# 4 \rightarrow \# 6$. Teaching these skills in this order would seem logical.
Age 15.0

\#1. winding thread (weave warp and weft into a ball for use in weaving cloth)

Age 16.0

\#2. stretching warp on a loom ('warping' in weaving terminology)

\#3. stretching warp on a loom (using 3 colors of thread)

\#4. stretching warp on a loom (using 5 colors of thread)

\#6. stretching warp on a loom (using splash pattern thread)

Age 17.0

\#5. stretching warp on a loom (using 10 colors of thread)

2 ) The Figure for "Weaving fabric on a loom" (Figure 4-2), is composed of 12 clothes-making skills (Table 1, \#7-\#18). The skill with lowest average age of skill acquisition and difficulty is "\#7 


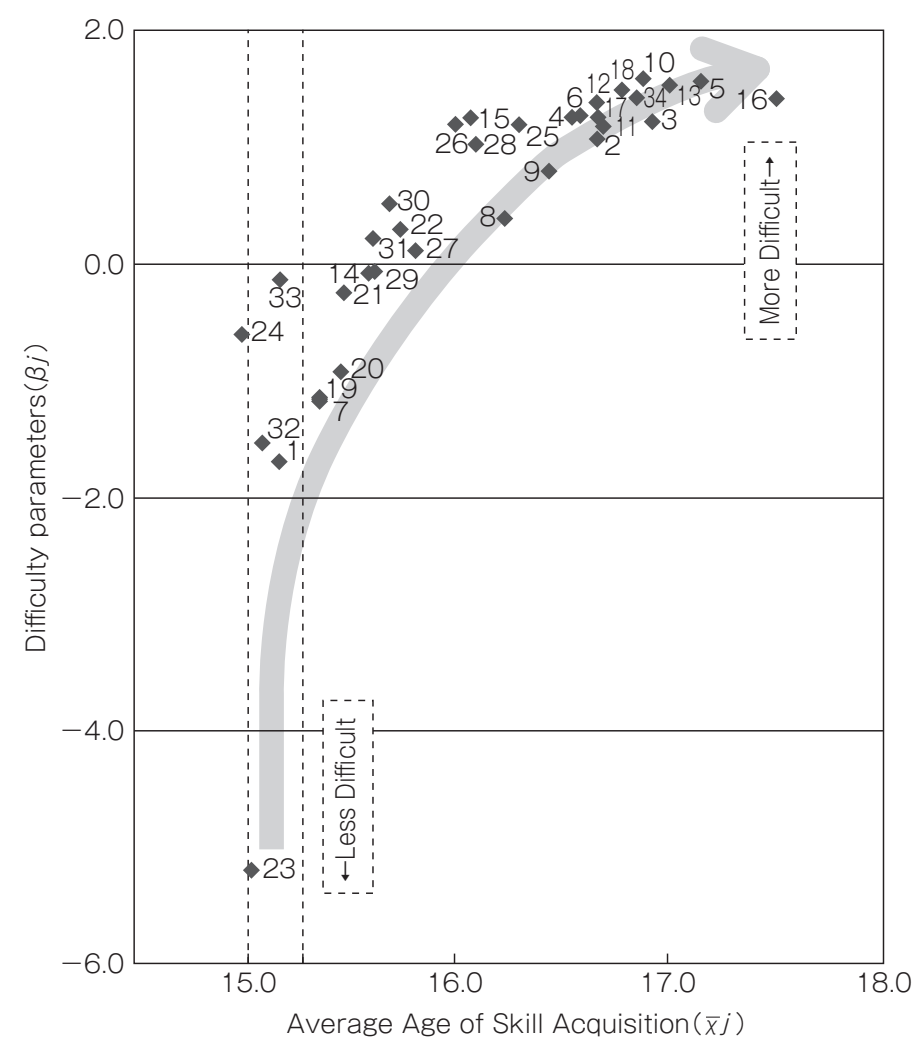

Figure 3 Average Age of Clothes Making Skill Acquisition (34 skills) and Level of Difficulty parameters for Karen Teenage Women (106 women)

winding thread [using a weaving implement (shuttle) to wind weft thread into a spiral]" at 15.4 years. This skill is constantly used during weaving, and so it is logical that this is the first skill acquired before learning to weave. The weaving skills in this type of skill (\#8-\#18) all depend on the acquisition of \#7.

Around the same time as acquiring \#7 at age 15.4, women learn the most basic among plain weaving skills [\#14. weaving fabric on a loom (plain weave, 'one up, one down'weave)] (15.6 years). These two skills can be considered the fundamental skills for this type of skill.

Sorting the 12 skills in this figure by age gives the following results. Beginning at age 16, women concentrate on learning the relatively difficult skills related to weaving patterns into cloth. These skills, in order of increasing difficulty, are \#8 $\rightarrow$ \#9 $\rightarrow \# 11 \rightarrow \# 15 \rightarrow \# 17 \rightarrow \# 12 \rightarrow \# 18 \rightarrow \# 10$. Teaching skills in this order would seem logical.

Age 15.0

\#7. winding thread [using a weaving implement (shuttle) to wind weft thread into a spiral] \#14. weaving fabric on a loom (plain weave, 'one up, one down'weave)

Age 16.0

\#8. weaving fabric on a loom (splash pattern)

\#9. weaving fabric on a loom (using 3 heddles) \#10. fabric weaving (using 5 heddles)

\#11. weaving fabric on a loom (3 colors alternating weft)

\#12. weaving fabric on a loom (5 colors alternating weft)

\#15. weaving fabric on a loom ( 'two up, one down' weave, half-basket weave, crossing 2 warp threads and 1 weft thread) 

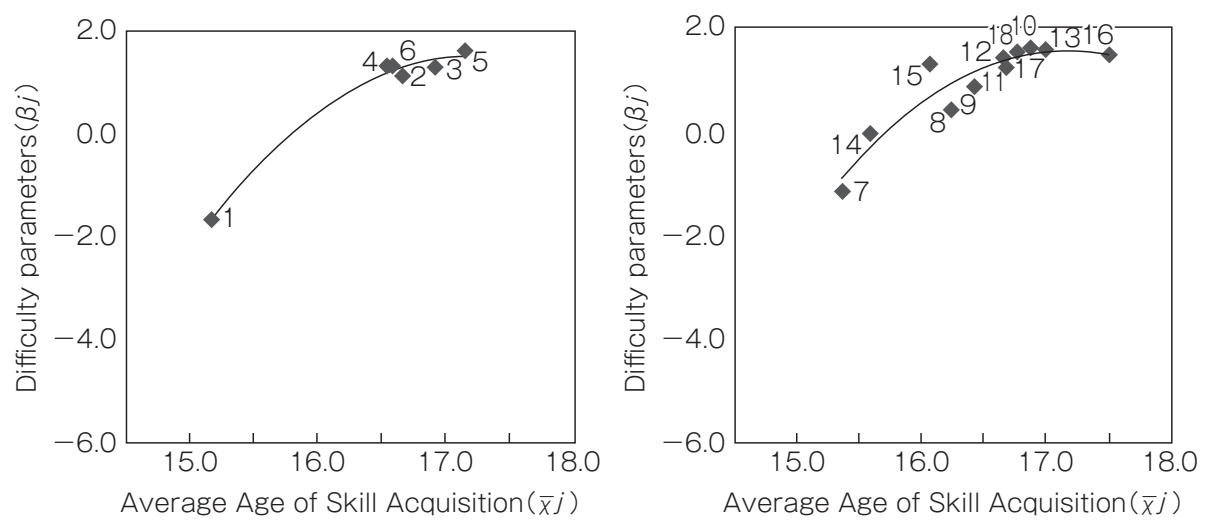

Figure 4-1. Stretching warp on a loom(6 skills) Figure 4-2. Weaving fabric on a loom(12 skills)
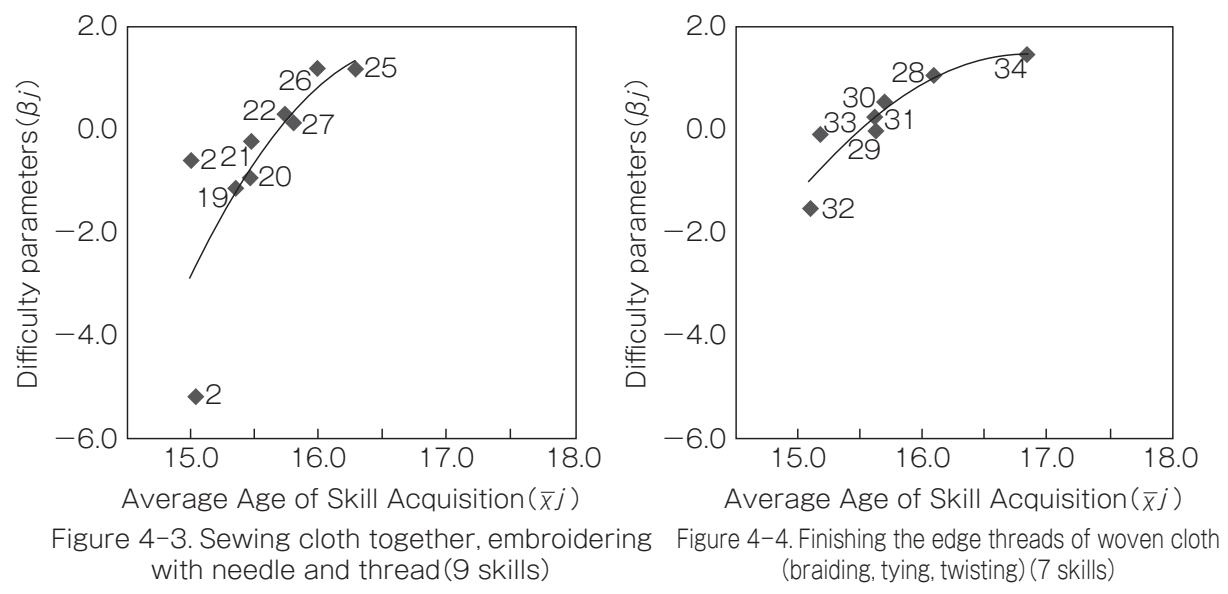

Figure 4-3. Sewing cloth together, embroidering with needle and thread ( 9 skills)

(braiding, tying, twisting) (7 skills)

Figure 4 Indifference Curves, by Type of Skill and Difficulty parameters, of Average Age of Acquisition of Clothes-Making Skills (34 skills) for Teenage Karen Women (106 women)

\#17. weaving fabric on a loom (inserting 2 alternating colors of weft)

\#18. weaving fabric on a loom (embroidery, taking weft with finger or needle to insert pattern while weaving)

Age 17.0

\#13. weaving fabric on a loom (10 colors alternating weft)

\#16. weaving fabric on a loom (alternating two weft thread and one weft thread)

For example, if the 8 skills that are intensively acquired at age 16 were taught in a school setting with limited time, teaching priorities could be assigned by the discrimination $(\alpha j)$ value of each skill.

As mentioned before, low discrimination $(\alpha j)$ skills are not always necessary to clothes-making skills. Using this characteristic, class time could be used more effectively by spending time on high discrimination skills rather than low discrimination skills. According to Figure 2, skills should be acquired in the following order (descending discrimation) $\# 12 \rightarrow \# 11 \rightarrow \# 9 \rightarrow \# 17 \rightarrow \# 18 \rightarrow \# 10$ $\rightarrow \# 8 \rightarrow \# 15$.

3 ) The "Sewing cloth together, embroidering with needle and thread" figure (Figure 4-3) is composed of 9 clothes-making skills (Table 1 , 
\#19-\#27). Sorting the 9 skills in this figure by age gives the following results. There is a tendency to acquire seam stitching skills at age 15 , and at 16 acquire embroidering skills used to decorate cloth. Age 15.0

\#19. seam stitching (stitch is chevron-shaped) \#20. seam stitching (stitch is $x^{-}$-shaped) \#21. seam stitching ( stitch is $\mathrm{z}^{-}$-shaped) \#22. seam stitching (stitch is bowtie-shaped) \#23. seam stitching (diagonal stitch)

\#24. seam stitching (diagonal stitch between fold of cloth and other piece of cloth)

\#27. beadwork

Age 16.0

\#25. embroidering (satin stitch)

\#26. embroidering (chain stitch)

Ordering skills acquired at age 15 by increasing difficulty gives \#23 $\rightarrow \# 19 \rightarrow \# 20 \rightarrow \# 24 \rightarrow \# 21 \rightarrow \# 27$

$\rightarrow \# 22$. Teaching priority (high to low) based on discrimination gives \#22 $\rightarrow \# 21 \rightarrow \# 27 \rightarrow \# 20 \rightarrow \# 19$ $\rightarrow \# 24 \rightarrow \# 23$.

In attempting to optimize skill acquisition in this research, it is important to consider age, difficulty and discrimination.

4 ) The Figure for "Finishing the edge threads of woven cloth (braiding, tying, twisting, hemming)"

Figure 4-4 is composed of 7 clothes-making skills (Table 1,\#28-\#34). From this figure, we find that at age 15.6 women intensively acquire skills $\# 29$, \#30, \#31, and learn each for a fixed period of time.

Age 15.0

\#29. hemming with thread (brancket stitch)

\#30. tying the end of weaving thread

\#31. making a stopper knot at end of weaving thread (overhand knot)

\#32. braiding (take $10+$ threads from edge of cloth, separate into 3 equal parts, braid alternating, diagonally)

\#33. twisting the end of weaving thread

Age 16.0

\#28. sewing braided cord to edge of cloth (edge of sleeve, collar, etc.)

\#34. making twisted thread (making a stopper knot after twisting end of weaving thread)

In this way, looking at the four figures, with difficulty for each skill type, and its relationship to age, we can obtain an indifference curve, in microeconomics terminology.

\section{Order of Instruction by Type of Skill}

Finally, we calculated mean values of the average age of skill acquisition $(\bar{x} j)$ and standard deviation for each type of skill (Table 2).

When teaching the 34 skills by type of skill, the timing of acquisition can be further optimized by ordering the type of skill by decreasing mean values of the average age of skill acquisition $(\bar{x} j)$, yielding 3$) \rightarrow 4) \rightarrow 2) \rightarrow 1$ ).

\section{Conclusion}

In this research, we considered the progressive nature of these skills by grouping them by type of skill, and deriving indifference curves using the variables 'average age of skill acquisition' and 'difficulty'. These two variables showed a positive correlation, and there were no internal inconsistencies when assigning the order of acquisition of the 34 skills. When considering an educational system, it seems rational to consider skills that appear close to the origin of the curves to be fundamental skills, and assign the order of instruction of skills as the follow the progress of the curve to the upper right. As explained above, the systematization of skills instruction and acquisition is made possible by adding the item 'average age of skill acquisition' to the IRT information.

\section{Acknowledgments}

This data collection used in this research was made possible by the cooperation of countless 
Table 2 The mean value $(\bar{x} j)$ and standard deviation $(\sigma j)$ of the average age of skill acquisition $(\bar{x} j)$ of 34 clothes making techniques, by type of skill

\begin{tabular}{lcc}
\hline \multicolumn{1}{c}{ Type of Skill } & $\begin{array}{c}\text { Mean } \\
\text { Value }(\bar{x} j)\end{array}$ & $\begin{array}{c}\text { Standard } \\
\text { Deviation }(\sigma j)\end{array}$ \\
\hline 1) Stretching warp on a loom & 16.51 & 0.69 \\
\hline 2) Weaving fabric on a loom & 16.49 & 0.60 \\
\hline $\begin{array}{l}\text { 3) Sewing cloth together, embroider } \\
\text { ing with needle and thread }\end{array}$ & 15.58 & 0.43 \\
\hline 4) Finishing the edge threads of \\
$\begin{array}{l}\text { Woven cloth (braiding, tying, } \\
\text { twisting, hemming) }\end{array}$ \\
\hline
\end{tabular}

people in Chiangmai. We would like to thank the Karen women of Samoeng and Chiangmai, Mrs. Rutuu of the Sgaw Karen and Mrs. Shibu, the people of $\mathrm{P}$ village in Doisakhet, Chiangmai,, Mr. Thaworn Foofuang (Former coordinater, the Tribal Museum, Chiangmai, the Ministry of Social Development and Human Security) for his invaluable advice, and Mr. Somkait Chamlong.

Heartfelt thanks to Dr. Masao Ayabe (Department of Cultural Anthropology, Tokyo Metropolitan University) for providing local interpretation in the Northern Thai language.

Funding for this study was provided by the Japan Society for the Promotion of Science : Grant-in-Aid for Scientific Research (C), Study Number 20500654, Shimoda, Atsuko.

note: The Karen ethnic group live throughout the mountainous regions of eastern Myanmar and northern Thailand. Linguistically, the Karen language is often categorized as part of the TibetoBurman group of the Sino-Tibetan language family. Traditionally animist, Christianity and Buddhism are also widespread. The Karen are agrarian.

\section{References}

Hewes, G. W. (1955) World Distribution of Certain Postural Habits, Am Anthropol, 57, 231-244 Iwata, K. (1971) Minorities of Southeast Asia, NHK
Books, 1-246 (in Japanese)

Kawada, J. (1988) Technological aspects of the technique of the body: preliminary remarks, Annual Review of Social Anthropology, 14, 1-41 (in Japanese)

Kawada, J. (1991) Notes on "the Techniques of the Body" among West African peoples, Journal of Anthropological Society of Nippon, 99, 377-391

Matsuura, Y. (1968) Factor Structure of Motor Ability, Fumaido, 1-358 (in Japanese)

Mauss, M. (1950 (1936) ) 'Les Techniques du Corps' , Sociologie et Anthropologie, Presses Universitaires de France, 363-386 [Arichi, T. and Yamaguchi, T. (translators) (1976) Sociology and Anthropology II , Koubundou, 121-156]

Mori, K. (1985) Learning Process of Manufacturing Techniques-Changes in Competency Structures that Accompany Skill Acquisition, Training Section Report Series, 4, Inst of Vocational training, 1-195 (in Japanese)

Ohtomo, K. (1996) Introduction to Item Response Theory, Taishukan, 1-313 (in Japanese)

Shimoda, A. and Ohsawa, S. (2006) Succession of "the Techniques of the Body" for weaving as developmental task in a society without writing (Sgaw Karen Community) : stracturizing acquisition rate of weaving body techniques by age cohort, Japan Journal of Human Growth and Development Research, 30, 1-6 (in Japanese)

Shimoda, A. and Ohsawa, S. (2008) A process of "the technique of the body" for weaving in the society without writing (Sgaw Karen Community) : esti- 
mation by item response theory with two parameters, Japan Journal of Human Growth and Development Research, 37, 1-8 (in Japanese)

Tanabe, S. (1997) Magic as practical knowledge : body techniques used by Northern Thai spirit-medi- ums, The Japanese Journal of Ethnology, 62, 394401 (in Japanese)

Toyoda, H. (2002) Primer on Item Response Theory, Asakura Publishing, 1-177 (in Japanese)

(Received 5.27.2011; Accepted 7.14.2011)

\section{技術習得年齢, 識別力, 困難度の解析からみた 身体技術指導年齢の最適化問題}

\section{下田 敦子 大澤 清二 大久保智哉}

\section{抄録}

無文字社会において伝承されてきた身体技術（衣類を製作する技術）は急速な社会の変化に伴って消失 の危機を孕んでいる。現地ではこれを保存するべく職業訓練学校では技術伝承の実技指導法や力リキュラ ムを模索している。このニーズに応えるために，衣類製作に使用される道具，諸技術要素とその指導シス テムを解明しつつある。今回は伝統的衣類製作技術を 34 種類に精選し，被験者（106 名）のこれら技術の 習得の有無を手がかりにして, 項目反応理論による項目ごとの困難度パラメタ $\beta$ と識別力パラメタ $\alpha$ と, 平均習得年齢を求め，これらの情報から伝統技術要素の指導の最適時期を探索した。

タイ王国チェンマイ県のカレン人女性で衣類製作の経験を持つ 106 名を対象として, 上記 $\alpha$ と $\beta$, 項目 ごとの平均習得年齢 $\bar{x}$ とその標準偏差 $\sigma$ を求めた。 次いで $\bar{x}$ に対する $\alpha, \beta$ および $\sigma$ を 2 次元座標上に布 置し, 無差別曲線（indifference curve）を仮定してその分布を検討したところ, 明確に最適化問題を解く手 がかりを得ることが出来た。つまり，年歯に適した技術項目の指導順序に関する有力な情報をつかんだ。 なおこの研究方法は同種の技術要素指導や伝承に関する最適化問題に応用可能と考える.

Key words：無文字社会，発達課題，衣類製作，身体技術，項目反応理論

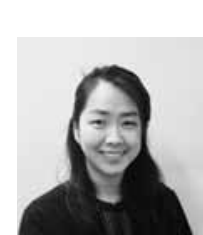

下田 敦子（しもだ あつこ）

現職：大妻女子大学人間生活文化研究所 助手

1969 年, 東京都出身. 専門は行動疫学.

タイ北部地域をフィールドとして, 身体文化の計量的な研 究をしています. 